\section{DIARY}

JUNE

10th Congress of the European

Academy for Paediatric Dentistry

Date: 3-6 June 2010

Venue: Harrogate International Centre

Tel: +44 (0)1423 855990

Email: nicola.peel@

hg3conference-secretariat.co.uk

www.eapd-2010.org.uk

Annual Meeting of the European

Society of Dental Ergonomics

Date: 4-5 June 2010

Venue: Ghent University Hospital,

Ghent, Belgium

Email: secretary-general@esde.org

www.esde.org

Lakeland Dental Symposium

Date: 11-12 June 2010

Venue: Lough Erne Golf Resort,

Belleek Road, Enniskillen

Tel: 02866329222

Email:events@belmoredentalstudio.co.uk

www.belmoredentalevents.co.uk

Training essentials - Managing stress

in yourself and your team

Date: 17 June 2010

Venue: BDA, London

Email: events@bda.org

Welsh Rural Postgraduate Unit,

Institute of Rural Health,

11th Annual Rural Dental Conference

Date: 25 June 2010

Venue: Gregynog Hall, Newtown, Mid Wales Tel: 01686650800

BDA Seminar - Introduction to

being an associate

Date: 25 June 2010

Venue: BDA, London

www.bda.org/events

\section{JULY}

The European Society of Lingual Orthodontics (ESLO) biennial congress

Date: 8-11 July 2010

Venue: Queen Elizabeth II Conference Centre, London

www.eslo-congress.com

The 18th International Federation of Dental Hygienists (IFDH) International Symposium on Dental Hygiene (ISDH)

Date: 1-3 July 2010

Venue: Scottish Exhibition \& Conference

Centre (SECC), Glasgow

www.bsdht.org.uk

\section{NEW GDC APPOINTMENT}

Ian Todd is to take over as Interim Chief Executive and Registrar of the General Dental Council (GDC) as Alison White concludes her time in the role.

Ian will hold the post until the arrival of Evlynne Gilvarry later this year, who was recently announced as the permanent appointment. Alison Lockyer, Chair of the General Dental Council said, 'I am pleased to welcome Ian to the interim role. He brings a wealth of experience in fitness to practise, a key focus for improvement at the GDC.'

Ian joins the GDC from the Nursing and Midwifery Council where he was Director of Fitness to Practise. Prior to entering the world of regulation Ian spent 13 years in the NHS ambulance service in both clinical and management roles, including at director level. He was a paramedic registrant of the Health Professions' Council until 2008.
In further news, the GDC is asking dental professionals to double-check that their registered address is up to date. Dental professionals can check their details by logging on to www.gdcuk.org and searching the registers using their registration number.

Registration Projects Manager Sarah Arnold said, 'When registrants move from their registered address, whether home or work, the GDC should be on the check-list of organisations they need to contact. We regularly send things out by post - such as Annual Retention Fee information, Annual Practising Certificates and the Gazette. If these haven't been arriving, it's worth making sure we have the right contact details. The registered address can be of a home, a practice or even a Post Office Box number as long as it is somewhere we can get in touch, but remember, the address you give will be published on our website.'

\title{
FOCUS ON PATIENT SAFETY CURRICULUM AT WHO
}

Professor Raman Bedi has been appointed as an expert consultant to the WHO Patient Safety Programme for the multi-professional Patient Safety Curriculum.

In addition, he will be co-chairing the official review of the WHO Patient Safety Curriculum Guide (PSCG), together with the Organization for Safety and Asepsis Procedures (OSAP), the International Federation of Dental Educators and Associations (IFEDA) and other leading global medical profession associations. The curriculum will be launched globally in early 2011.

The multi-professional WHO Patient Safety Curriculum Guide was first published in 2009 to provide medical schools with guidelines for teaching patient safety, and has since been downloaded by more than 1,000 institutions in 100 countries. In growing recognition of the harms caused by healthcare, the WHO initiated a review of the Guide and invited the FDI World Dental Federation to participate as a primary partner in the project, together with the International Council of Midwives and other members of the World Health Professions Alliance (WHPA).

On this theme, the chair of the Patient Safety in Dentistry (India) Council has called upon the Dental Council of India to make it mandatory for all dental students to demonstrate active immunity against hepatitis $B$ at the time of their admission. This resolution is to be considered by the Dental Council of India at its May 2010 meeting.

Raman Bedi has also been appointed as Honorary Professor of Public Health Dentistry at ITS Centre for Dental Studies and Research, Ghaziabad, India. This is in recognition for his contribution to improving the oral health of the Indian population and adds to his existing honorary chair at the Maulana Azad Institute of Dental Sciences, New Delhi.

Professor Bedi is Head of the International Centre for Child Oral Health and Director of the Global Child Dental Health Taskforce (GCDHT).

Details of the review will be finalised during a consensus meeting at the 2010 OSAP Annual Symposium in June. 